\title{
Pummelo (Citrus maxima Merill) Seedlings Growth as Influenced by Plant Growth Regulators and Macronutrients
}

\author{
H.R. Harsha ${ }^{1}$, Venkata Rao ${ }^{2 *}$, K.J. Dayamani ${ }^{1}$ and M. Shivanna ${ }^{1}$ \\ ${ }^{1}$ College of Horticulture, UHS campus, GKVK Post, Bengaluru-560 065, Karnataka, India \\ ${ }^{2}$ Department of Fruit Science, College of Horticulture, Mysore-571 130, Karnataka, India \\ *Corresponding author
}

\section{A B S T R A C T}

Keywords

Growth regulators,

Macronutrients,

Growth, Pummelo.

Article Info

Accepted:

15 October 2017

Available Online:

10 December 2017
An experiment was conducted during 2016-17 at College of Horticulture, Bengaluru to study the pummelo seedlings growth as influenced by plant growth regulators and macronutrients. The treatment with $\mathrm{GA}_{3} 150 \mathrm{ppm}+$ NAA $150 \mathrm{ppm}$ has recorded the maximum seedling height $(49.30 \mathrm{~cm})$, seedling diameter $(0.64 \mathrm{~cm})$, number of leaves $(42.90)$, leaf area $(32.53$ $\mathrm{cm}^{2}$ ), fresh and dry weight of seedlings (48.67 and $12.87 \mathrm{~g}$ respectively), number of primary and secondary roots (52.07), Length of primary root $(47.53 \mathrm{~cm})$, Root volume $\left(13.43 \mathrm{~cm}^{3}\right)$ and fresh and dry weight of root (13.07 and $5.37 \mathrm{~g}$ respectively) of pummelo seedlings.

\section{Introduction}

Pummelo (Citrus maxima Merill or Citrus grandis Osbeck) belongs to family Rutaceae and is probably originated in the region of Thailand and Malaysia. It is called by various names such as Chakotha, Sadaphal, Chinese grapefruit, Batavia lemon, Batabi lebu, Pomelo, Pomello, Pummelo, Pommelo, Pamplemousse, Jabong (Hawaii) and Shaddock.

The growth of pummelo seedlings is slow and the growers have to wait for one year to take up budding or grafting operation to market them or plant them. Chemical growth regulators like $\mathrm{GA}_{3}$ (Gibberellic acid) and NAA (Naphthalene Acetic Acid) perform an important role in growth and development of plants by increase in cell enlargement and division, increase in cellular spaces in the mesocarpic cells and higher translocation of photosynthates and mineral nutrients in plants (Krishnamoorthy, 1993)

Similarly, there is a major role of macronutrients in plant. However some macronutrients, like nitrogen which helps in utilization of carbohydrates and components of proteins, protoplasm and cholorophyll. While phosphorus helps in development of roots and potassium is involved in standard stomatal regulation and increases disease resistance in plants (Singh, 2014). Keeping in view of the role of growth regulators and macronutrients, the present study was 
conducted to see weather quick growth could be achieved with the use of these at different concentrations on pummelo seedlings. The present investigation was carried to get early marketable plants and thereby reducing the cost of production.

\section{Materials and Methods}

The experiment on "Pummelo (Citrus maxima Merill) seedlings growth as influenced by plant growth regulators and macronutrients" was conducted at Regional Horticultural Research and Extension Centre, University of Horticultural Sciences campus, GKVK, Bangalore 560 065, during the year 2016-17. The experiment was laid out in completely randomized design with three replications. The experiment comprised of thirteen treatments with the combinations of plant growth regulators, namely Gibberellic acid $\left(\mathrm{GA}_{3}\right)$ and Naphthalene acetic acid (NAA). Macronutrients namely Urea, water soluble NPK and $\mathrm{KNO}_{3}$ were used at different concentrations.

Seedlings were raised in the polybags. The polybags were prefilled with Red soil, FYM and Sand (2:1:1). The germination period is about 45 days from sowing. The required quantities of plant growth regulators and macronutrients were prepared through stock solution with their different concentrations and were sprayed as per the treatment for seedlings. The first spray was taken up 30 days after germination and second spray was taken 60 days after germination and observation were recorded at 150 days after germination.

\section{Results and Discussion}

The results in Table 1 (Fig. 1) revealed that the maximum seedling height, seedling diameter, number of leaves, leaf area, fresh and dry weight of seedling $(49.30 \mathrm{~cm}, 0.64$ $\mathrm{cm}, 42.90,32.53 \mathrm{~cm}^{2}, 48.67 \mathrm{~g}$ and $12.87 \mathrm{~g}$ respectively) were recorded in the treatment $\mathrm{GA}_{3} 150 \mathrm{ppm}+\mathrm{NAA} 150 \mathrm{ppm}\left(\mathrm{T}_{3}\right)$ at 150 days after germination and minimum was recorded in control i.e., water spray $\left(\mathrm{T}_{13}\right)$. The application of growth promotive substances increased the plant height and seedling diameter, such effect was due to increased photosynthetic activity, enhancement in the mobilization of photosynthates and change in the membrane permeability (Shukla et al., 1997). The vigorous growth induces more number of branches which in turn facilitates better harvest of sunshine by the plants to produce more number of leaves. These results obtained on this aspect are in agreement with Marler and Mickelbert (1992) in carambola and Kawthalkar and Kunte (1974) in rangpur lime. This also helps in invigoration of physiological process of plant and stimulatory effect of chemicals to form new leaves at faster rate (Sharma et al., 1991) and mobilization of water $\&$ nutrients transported at higher rate which might have promoted more production of photosynthetic product and translocated them to various plant parts which might have resulted in better growth of the seedlings and hence more fresh and dry weight. The results are in conformity with the findings of Misra and Jaiswal (2001) in bael, Monselise and Halevy (1962) in citrus.

The results as shown in Table 2 (Fig. 2) revealed that the maximum number of primary and secondary roots, length of primary root, root volume, fresh and dry weight of root $\left(52.07,47.53 \mathrm{~cm}, 13.43 \mathrm{~cm}^{3}\right.$, $13.07 \mathrm{~g}$ and $5.37 \mathrm{~g}$ respectively) were recorded in the treatment $\mathrm{GA}_{3} 150 \mathrm{ppm}+$ NAA $150 \mathrm{ppm}\left(\mathrm{T}_{3}\right)$ at 150 days after germination and minimum was recorded in control i.e., water spray $\left(\mathrm{T}_{13}\right)$. The restorer effect of NAA on apical dominance which promote root initiation, more nutrient uptake and root cell elongation and good growth of the roots. 
Table.1 Effect of foliar spray of growth regulators and macronutrients on morphological characters of pummelo seedlings

\begin{tabular}{|c|c|c|c|c|c|c|}
\hline Treatments & $\begin{array}{c}\text { Seedling } \\
\text { height } \\
(\mathrm{cm})\end{array}$ & $\begin{array}{c}\text { Seedling } \\
\text { diameter } \\
(\mathrm{cm})\end{array}$ & $\begin{array}{l}\text { Number } \\
\text { of leaves }\end{array}$ & $\begin{array}{l}\text { Leaf } \\
\text { area } \\
\left(\mathrm{cm}^{2}\right) \\
\end{array}$ & $\begin{array}{c}\text { Fresh } \\
\text { weight } \\
\text { (g) }\end{array}$ & $\begin{array}{c}\text { Dry } \\
\text { weight } \\
\text { (g) }\end{array}$ \\
\hline $\mathrm{T}_{1}-\mathrm{GA}_{3} 50 \mathrm{ppm}+\mathrm{NAA} 50 \mathrm{ppm}$ & 47.00 & 0.61 & 39.13 & 29.48 & 43.33 & 11.13 \\
\hline $\mathrm{T}_{2}-\mathrm{GA}_{3}$ 100ppm + NAA 100ppm & 46.40 & 0.63 & 39.83 & 30.98 & 45.33 & 11.70 \\
\hline $\mathrm{T}_{3}-\mathrm{GA}_{3}$ 150ppm + NAA 150ppm & 49.30 & 0.64 & 42.90 & 32.53 & 48.67 & 12.87 \\
\hline $\mathrm{T}_{4}$ - Urea $1 \%$ & 42.90 & 0.58 & 37.20 & 29.18 & 44.13 & 11.17 \\
\hline $\mathrm{T}_{5}$ - Urea $2 \%$ & 42.23 & 0.59 & 39.03 & 26.46 & 39.77 & 10.90 \\
\hline $\mathrm{T}_{6}$ - Urea $3 \%$ & 42.57 & 0.62 & 41.80 & 28.75 & 38.97 & 10.93 \\
\hline $\mathrm{T}_{7}-$ Water soluble NPK 1\% (19:19:19) & 43.17 & 0.57 & 35.87 & 28.94 & 36.53 & 10.47 \\
\hline $\mathrm{T}_{8}-$ Water soluble NPK 2\% $(19: 19: 19)$ & 45.17 & 0.57 & 37.17 & 27.94 & 42.97 & 10.80 \\
\hline $\mathrm{T}_{9-}$ Water soluble NPK 3\% (19:19:19) & 42.93 & 0.60 & 39.23 & 30.78 & 39.93 & 10.90 \\
\hline $\mathrm{T}_{10}-\mathrm{KNO}_{3} 1 \%$ & 46.20 & 0.59 & 36.13 & 27.58 & 42.43 & 10.90 \\
\hline $\mathrm{T}_{11}-\mathrm{KNO}_{3} 2 \%$ & 42.33 & 0.58 & 38.53 & 27.64 & 37.13 & 10.63 \\
\hline $\mathrm{T}_{12}-\mathrm{KNO}_{3} 3 \%$ & 43.30 & 0.61 & 40.97 & 29.76 & 43.00 & 11.23 \\
\hline $\mathrm{T}_{13}-$ Water spray (control) & 38.53 & 0.52 & 34.83 & 25.69 & 29.23 & 7.60 \\
\hline $\begin{array}{r}\text { SE.m } \pm \\
\end{array}$ & 1.65 & 0.01 & 1.46 & 1.17 & 1.65 & 0.48 \\
\hline $\mathrm{CD}$ at $5 \%$ & 4.79 & 0.03 & 4.24 & 3.39 & 4.79 & 1.40 \\
\hline
\end{tabular}

Table.2 Effect of foliar spray of growth regulators and macronutrients on root parameters of pummelo seedlings

\begin{tabular}{|c|c|c|c|c|c|}
\hline Treatments & $\begin{array}{c}\text { Number of } \\
\text { primary and } \\
\text { secondary roots }\end{array}$ & $\begin{array}{l}\text { Length of } \\
\text { primary } \\
\text { root }(\mathrm{cm})\end{array}$ & $\begin{array}{c}\text { Root } \\
\text { volume } \\
\left(\mathrm{cm}^{3}\right)\end{array}$ & $\begin{array}{c}\text { Fresh } \\
\text { weight } \\
\text { (g) }\end{array}$ & $\begin{array}{c}\text { Dry } \\
\text { weight } \\
\text { (g) }\end{array}$ \\
\hline $\mathrm{T}_{1}-\mathrm{GA}_{3} 50 \mathrm{ppm}+\mathrm{NAA} 50 \mathrm{ppm}$ & 51.23 & 44.30 & 11.02 & 11.80 & 4.87 \\
\hline $\mathrm{T}_{2^{-}} \mathrm{GA}_{3}$ 100ppm + NAA 100ppm & 51.93 & 44.80 & 12.00 & 12.13 & 4.93 \\
\hline $\mathrm{T}_{3^{-}} \mathrm{GA}_{3}$ 150ppm + NAA 150ppm & 52.07 & 47.53 & 13.43 & 13.07 & 5.37 \\
\hline $\mathrm{T}_{4^{-}}$Urea $1 \%$ & 46.73 & 37.30 & 9.90 & 10.60 & 4.47 \\
\hline $\mathrm{T}_{5}$ - Urea $2 \%$ & 50.07 & 38.70 & 11.10 & 10.03 & 4.23 \\
\hline $\mathrm{T}_{6^{-}}$Urea $3 \%$ & 43.90 & 38.53 & 11.40 & 10.40 & 4.20 \\
\hline $\mathrm{T}_{7-}$ Water soluble NPK 1\% (19:19:19) & 46.40 & 43.43 & 11.47 & 11.03 & 4.27 \\
\hline $\mathrm{T}_{8^{-}}$Water soluble NPK 2\% (19:19:19) & 45.47 & 40.80 & 10.97 & 12.10 & 4.87 \\
\hline $\mathrm{T}_{9^{-}}$Water soluble NPK 3\% (19:19:19) & 46.77 & 38.40 & 11.40 & 9.57 & 3.93 \\
\hline $\mathrm{T}_{10^{-}} \mathrm{KNO}_{3} 1 \%$ & 45.77 & 40.53 & 11.43 & 11.37 & 4.10 \\
\hline $\mathrm{T}_{11}-\mathrm{KNO}_{3} 2 \%$ & 47.10 & 40.90 & 11.20 & 11.20 & 3.83 \\
\hline $\mathrm{T}_{12}-\mathrm{KNO}_{3} 3 \%$ & 45.00 & 41.40 & 11.73 & 11.87 & 4.83 \\
\hline $\mathrm{T}_{13}-$ Water spray (control) & 40.27 & 36.67 & 9.37 & 9.23 & 3.17 \\
\hline SE.m \pm & 1.85 & 1.99 & 0.53 & 0.55 & 0.20 \\
\hline $\mathrm{CD}$ at $5 \%$ & 5.38 & 5.80 & 1.55 & 1.60 & 0.58 \\
\hline
\end{tabular}


Fig.1 Morphological characters of pummelo seedlings as influenced by foliar spray of growth regulators and macronutrients

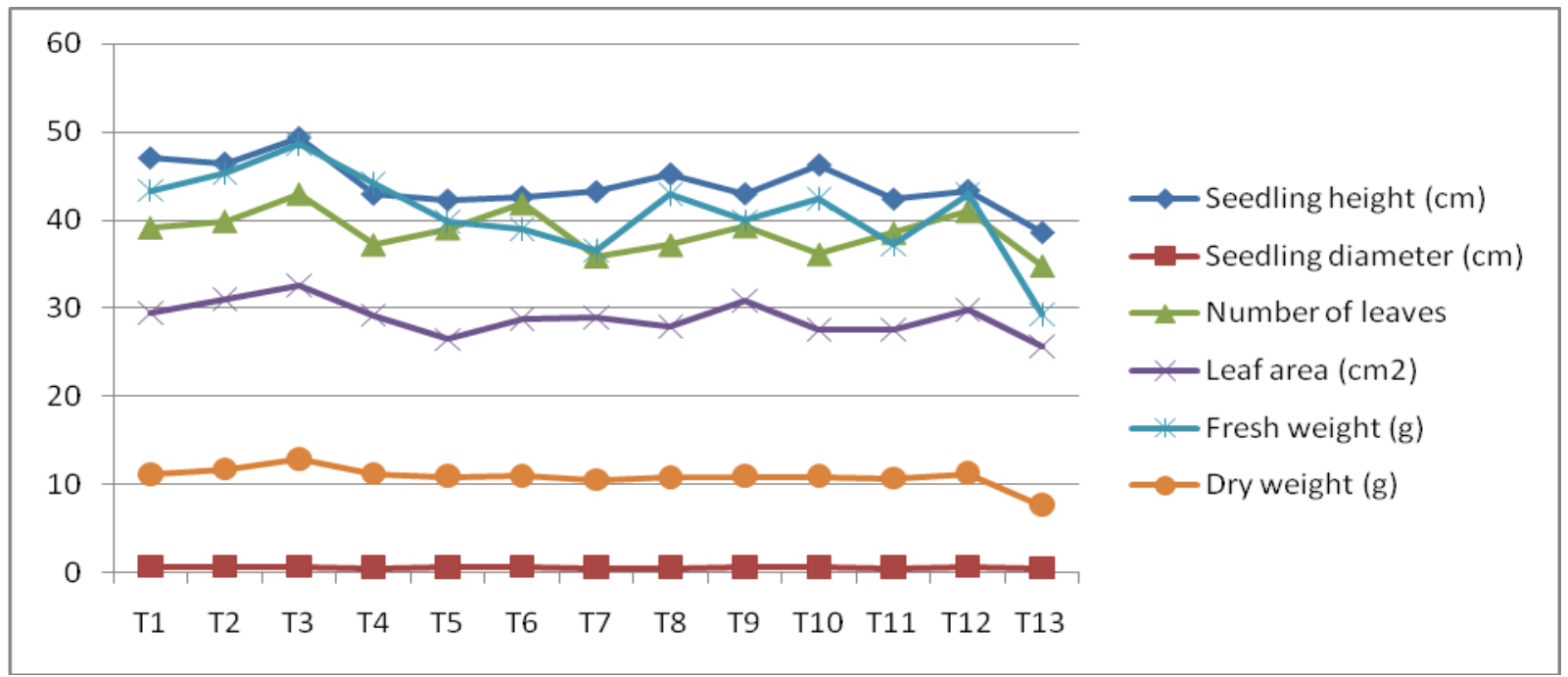

Fig.2 Root parameters of pummelo seedlings as influenced by foliar spray of growth regulators and macronutrients

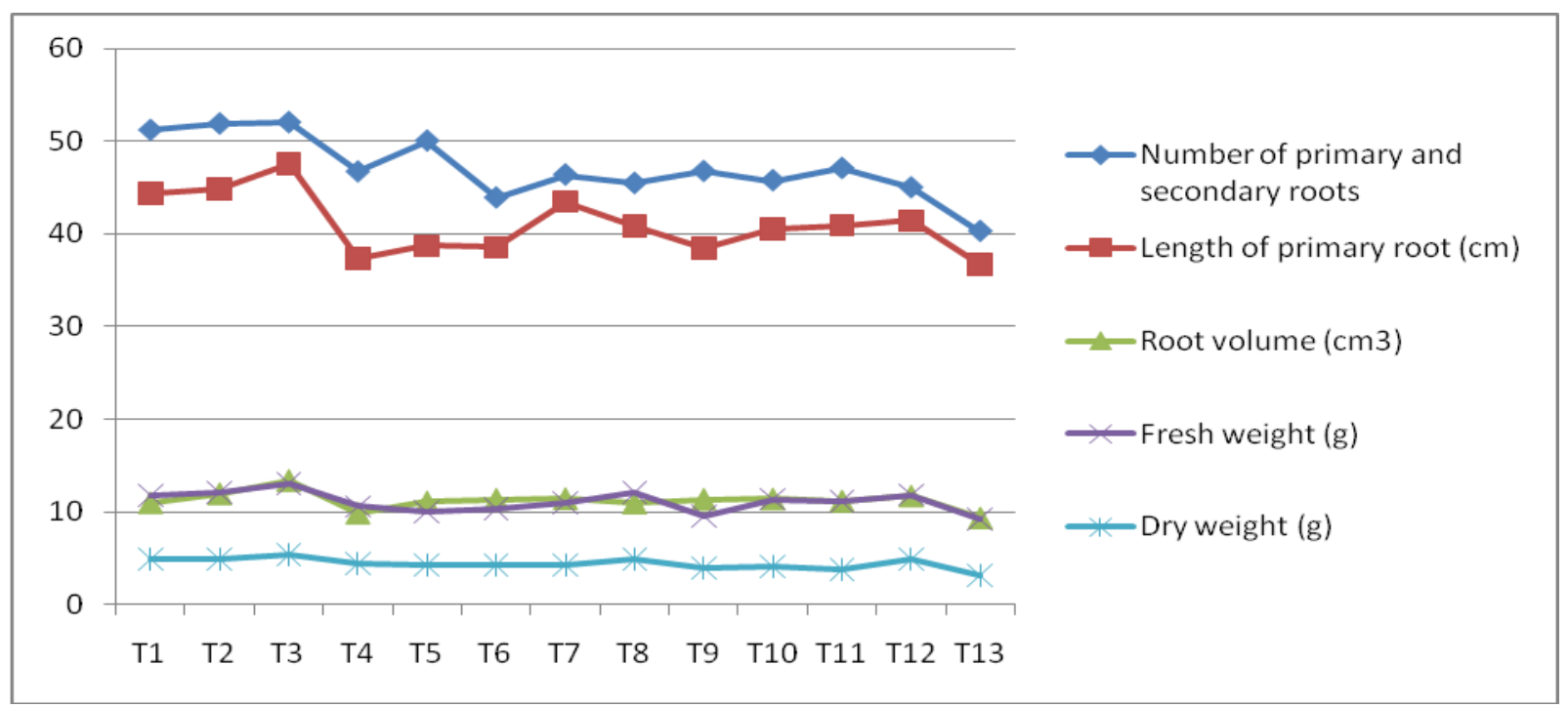

$\mathrm{GA}_{3}$ increases somatic uptake of nutrients, causing cell elongation and enhanced hydrolysis of carbohydrates caused by auxins. The results obtained in the present studies are in agreement with that reported by Misra and Jaiswal (2001) in bael, Singh and Sheo (2000) and Karunakaran et al., (2007) in citrus species and Virendra and Shafaat (1996) and Wagh et al., (1998) in aonla. The maximum fresh and dry weight in this treatment was due the favorable effect of NAA which increases auxin level in the roots that stimulated more root initiation, more nutrient uptake and root cell elongation, thus resulting into increased tap root length resulted in increase in dry weight. The results are in conformity with the findings of Anjanawe et al., (2013) in papaya and Panchal et al., (2015) in khirni. From 
these results we can conclude that the growth regulators $\mathrm{GA}_{3} 150 \mathrm{ppm}+$ NAA $150 \mathrm{ppm}$ can be sprayed to get good growth of the seedling, so that early marketable size seedling can be produced and their by reducing the cost of production.

\section{References}

Anjanawe, S. R., Kanpure, R. N., Kachouli, B. K. and Mandloi, D. S. 2013. Effect of plant growth regulators and growth media on seed germination and growth vigour of papaya. Annals of Plant and Soil Research. 15(1): 31-34.

Karunakaran, G., Chithiraichelvan, R., Sakthivel, T., Sudhir and Kumar. 2007. Role of agrochemical sprays on enhancing the seedling growth of Citrus sp. Indian J. Agric. Sci., 77(5): 299-301.

Kawthalkar, M. P. and Kunte, Y. N. 1974. Effect of certain nursery management practices on growth of rangpur lime (Citrus limonia Osbeek) seedlings. S. Indian Hort., 22(3/4): 106-111.

Krishnamoorthy, H. N.1993. Physiology of plant growth and development. Atma Ram and Sons Publishers.

Marler, T. E. and Mickelbart, M. V. 1992. Application of gibberlic acid to stem enhances the carambola seedling growth. Hort. Sci., 27(2): 122-123.

Misra, K. K. and Jaiswal, H. R. 2001, Effect of plant bio regulators and potassium nitrate on seedling quality of bael (Aegle marmelos Correa). Adva. Hort. For., 8(2): 67-74.

Monselise, S. P. and Halvey, A. H. 1962. Effects of gibberellin and AMO-1618 on growth, dry-matter accumulation, chlorophyll content and peroxidase activity of citrus seedlings. Amer. J. Bot., 49(4): 405-412.

Panchal, G. P., Parasana, J. S., Patel, S. R. and Patel, M. V. 2015. Effect of different growing media and levels of IBA on growth and development of khirni (Manilkara hexandra roxb) seedlings cv. Local. Soc. Sci. Nature. 3(4): 379-383.

Sharma, M. C., Ughreia, P. P. U. and Jambukia, T. K. 1991. Effect of some plant growth regulators, chemicals and organic waste on germination and subsequent seedling growth of kagzi lime (Citus aurantifolia Swingle). Int. Sym. on citriculture, Nagpur. 51.

Shukla, K.C., Singh, O. P. and Samaiya, P. K. 1997. Effect of foliar spray of plant growth regulator and nutrient complex on productivity of soya bean var. JS 79 . Crop Res., 19(2): 213-215.

Singh, I. P. and Sheo, G. 2000. Effect of urea, $\mathrm{GA}_{3}$ and $\mathrm{ZnSO}_{4}$ spray on the growth of citrus seedlings in two species. Annals of Plant Physiology, 14(1): 39-42.

Singh, J. 2014. Basic horticulture. Kalyani publishers, pp: 168-174.

Virendra, S. and Shafaat, M. 1996. Effect of gibberellic acid and urea on growth and development of seedling rootstock of Aonla (Emblica officinalis Gaertn.). $J$. Appl. Hort. Navsari, 2(1/2): 116-121.

Wagh, A. P., Choudhary, M. H., Kulwal, L. V., Jadhav, B. J. and Joshi, P. S. 1998. Effect of seed treatment on germination of seed and initial growth of aonla seedling in polybags. $P K V$ Res. J., 22(2): 176- 177.

\section{How to cite this article:}

Harsha, H.R., Venkata Rao, K.J. Dayamani and Shivanna, M. 2017. Pummelo (Citrus maxima Merill) Seedlings Growth as Influenced by Plant Growth Regulators and Macronutrients. Int.J.Curr.Microbiol.App.Sci. 6(12): 1750-1754. doi: https://doi.org/10.20546/ijcmas.2017.612.198 